\title{
Our Unconscious Soul: A Re-look at Aristotle Descartes \& the Upanishads
}

\author{
Bradley Y. Bartholomew \\ Independent Researcher, France
}

Copyright $(2017$ by authors, all rights reserved. Authors agree that this article remains permanently open access under the terms of the Creative Commons Attribution License 4.0 International License

\begin{abstract}
This paper presents an original interpretation of the Upanishads that the inner self is located in the embryo brain region of the brain. This is the part of the brain already present in the embryo and consists of the brainstem, hypothalamus, thalamus, and midbrain. It is also the part of the brain that operates during dreaming and deep sleep and causes the transition from sleeping to waking states and the Upanishads state unequivocally that the self is responsible for these mental states. With the self-located in the embryo brain region, an entirely new interpretation of Aristotle's De Anima is presented which parallels the Upanishads in every respect; the inner self and Aristotle's 'soul' have identical functions and attributes. An Aristotelian First Principle is presented: Biology is the source of Consciousness; DNA is the source of Biology; Ergo DNA is the source of Consciousness. It has recently been discovered that our long-term memories are stored in the putamen during deep sleep. The putamen is located in the embryo brain region along with the pineal gland that secretes melatonin during deep sleep. Descartes famously located the soul in the pineal gland, and there is a high probability that the secretion of melatonin from the pineal gland during deep sleep is an unconscious operation of our soul involved in storing our long-term memories in the embryo brain region.
\end{abstract}

Keywords Michel Jouvet, Metaphysics, William James, Consciousness, REM, NREM, DNA, Philosophy of Mind

\section{Introduction}

It is generally believed that Hindu philosophy as expounded in the Upanishads is a totally different system of thought from the philosophy of Aristotle as expounded in his famous works Metaphysics and De Anima. This conviction that Hindu philosophy and Aristotelian philosophy are different schools of thought has indeed become entrenched in the history of humanity where the religion and culture of India is considered to be based on mysticism as a result of the inscrutable nature of their divine texts, whereas the teachings of Aristotle, which indeed are just as inscrutable, are considered to provide a firm foundation for the edifice of knowledge that has accrued in the West under the banner of scientific exploration and experimentation; such a noble enterprise being indeed the absolute antithesis of mysticism.

This notwithstanding the fact that Hindu philosophy and Aristotelian philosophy share a fundamental common theme which is completely clear and unambiguous and universally accepted; both these schools of thought are talking about a divine and immortal mind or soul. Indeed book Epsilon of Metaphysics begins by identifying the study of being with the study of God. Evidently if an interpretation can be found of the Upanishads which locates the inner self precisely in the brain and specifies its precise form and functions then the most efficacious way to test the veracity of that theory would be to see if it is also a good fit with what Aristotle says about the immortal soul or mind in his De Anima.

Descartes also had a lot to say about the soul, and in fact specifically nominated "the principal seat of the soul" as the pineal gland, so our interpretation of the Upanishads should also corroborate Descartes' insights as well.

\section{Parallels between Ancient Greek and Hindu Philosophy}

I will just take a moment to recall just how the philosophies of India and the Ancient Greeks both emerged completely independently of each other around the same period approximately 2,500 years ago and the fundamental precepts in these different philosophies enshrined in the dead languages of Sanskrit and Ancient Greek are virtually identical. Both the Hindus and the Ancient Greeks believed in a divine and immortal mind or soul that entered the body at conception, they believed in the transmigration of souls 
and they believed that the external world that we perceive through the senses is ultimately unreal. There were many ancient Greek philosophers and they all famously had different theories and they did not all agree with all three of these fundamental precepts above, but I think I can state without fear of contradiction that these three precepts were the dominant themes in early Greek philosophy and they enjoyed a broad consensus. Aristotle himself took issue with his master Plato on this topic of the unreality of the sensible world, but he was very clear on the fact that there is a divine and immortal soul which is actually tangible; it has form and matter or substance. We shall see in this regard that Aristotle's thinking substantially parallels that of the Hindus, and this is now about 2,300 years ago, and there still had not been any contact or exchange at all between the cultures of India and ancient Athens.

\section{The location of the Inner Self}

An article was published in the Indian Philosophical Quarterly in India in 1991 entitled Inner Self Located which locates the inner self in the embryo brain region. [1] This is the part of the brain that is already present in the embryo and it consists of the brainstem, hypothalamus, thalamus, and midbrain. In other words, the inner self is a real substantial part of the brain that has certain form and matter. I mention this at the outset because this will become crucial when I get onto the works of Aristotle. This is also the part of the brain that operates during sleep, that is to say it is responsible for the states of being awake and asleep; it is the source of our dreams and it is the part of the brain that causes the transition from the sleeping state to the waking state. The article to which I refer sets out a great deal of mainstream scientific evidence for all the above propositions and I don't propose to repeat that here. When I get onto the specific functions of the hypothalamus, thalamus, brainstem, and midbrain, you will see that it is beyond question that the embryo brain region is the part of the brain that operates during sleep.

It can be no exaggeration to say that the state of sleep is the very cornerstone of Hinduism. According to the Kaţha Upanişad, Puruşa, "who keeps awake and goes on creating desirable things, even when the senses fall asleep, is pure; and $\mathrm{He}$ is Brahman and $\mathrm{He}$ is called the Immortal. All the worlds are fixed on Him; none can transcend Him". [2] This Puruşa is called thus because He sleeps in all bodies (Puriśaya). [3] On an individual plane, this Puruşa or Brahman is known as Atman or the Self.

Two states of sleep are distinguished. There is first the dream consciousness which is evoked and sustained by the Self. "The blissful Self, revived by the impression of joy etc., is perceived in dream..." (Śańkarācārya's Commentary on the Taittirīya Upanişad). [2] "That radiant infinite being... puts the body aside in the dream state" (Bŗhadāranyaka Upanişad). [4] "Puruşa is the Supreme
Person, who himself becomes manifest as the persons in the eye and in dream..." (Śańkarācārya's Commentary on the Chāndogya Upanişad). [5]

There is secondly the state of deep sleep. "... then the sleeper becomes merged in Existence. He attains his own Self. Therefore, they speak of him as, 'he sleeps' for he attains his own Self” (Chāndogya Upanişad). [5] "... they reach daily (during sleep) this Brahman which is the goal" (Chāndogya Upanişad). [5] "In deep sleep Puruşa remains unmanifest and His organs fully withdrawn" (Śańkarācārya). [5]

The Self is consistently stated to be the agent that brings about the transition from the sleeping state to the waking state. “... it hastens back in a reverse way just to its previous state, that of waking..." (Brhadäranyaka Upanişad). [6] "As a large fish swims alternately to both banks (of a river) eastern and western even so does this infinite entity move alternately to both these states - those of dreaming and waking" (Bŗhadāraņyaka Upanişad). [6] "While the Self withdraws itself from all manifestations when it is in deep sleep, it projects itself in waking through the very channels through which it withdrew itself in sleep" (Bŗhadāranyaka Upanişad). [7]

Aristotle, the former pupil of Plato at the Academy, himself became the head of Lyceum, also in Athens and considered to be the world's first university. His major point of departure from Plato was this notion that that which changes is ultimately unreal, and now the prime task of the science of nature would be to find an explanation for this change. The Platonic soul had to have form and matter, otherwise his students wouldn't have anything to actually study at his Lyceum. Unfortunately, this raised more questions than it answered, and 2,300 years later scientists and philosophers and academics are still trying to figure out what he meant. Generally speaking, he was stating that there is a close correspondence between the arrangement and the functioning of any living being, but that is a long way from explaining how the soul, which definitely contained a divine component, could also have form and matter, or another term he used for this soul was "substance;" the divine soul had to have substance.

This of course is only perplexing for occidental philosophers, because it has been known all along in India that the divine inner self does indeed have substance, or form and matter. Śańkarācārya explains the meaning of the word anguşthamatrah - "of the size of a thumb, the lotus of the heart is of the size of a thumb; (and) as conditioned by the internal organ existing in the space within the lotus of the heart (the Self) has the size of a thumb". [2] The Chāndogya Upanişad states: "This Self of mine within the heart, is smaller than paddy or barley or mustard or a Shyamaka seed, or the kernel of Shyamaka seed. This Self of mine within the heart is greater than the earth, greater than the interminable space, greater than the heaven, greater than the worlds". [5]

"The desire is for knowing some special director of the 
mind" (Ananda Giri). "Who is that effulgent being who is the director of the mind and other organs towards their own objects and how does he direct?" (Śańkarācārya's Commentary on the Iśa Upanişad). [2] "He is all-pervasive, pure, bodiless, without wound, without sinews, taintless, untouched by sin, omniscient, ruler of the mind, transcendent and self-existent" (Iśa Upanişad). [2] This "special director," this "ruler" of the mind has to be the part of the brain that determines the growth and development of the whole brain, i.e., the embryo brain region.

"As the spider weaves out the web and again withdraws it, so the Jiva comes out to and goes back again to the wakeful and dreaming states respectively" (Brahmopaniśad). [7] This reference to the Self being like a spider that casts out and withdraws its web occur a number of times in the Upanişads. It is consistent with the self being located in the hrdaya (heart) that goes by drawing and giving. It would appear to be an illustration of the way the Self, lodged in the embryo brain region by means of the neurotransmitter, noradrenaline, draws the individual into sleep, and by means of the neurotransmitter, dopamine, wakes the individual up again. These neurotransmitters emanate from the embryo brain region in spider web pattern through the network of nerve channels in the brain. "And when a man is about to wake up, they emanate - they proceed to their respective functions - from the mind itself just like the rays radiating from the sun" (Śańkarācārya's Commentary on the Praśna Upanişad). [8]

That the embryo brain region is the location of the Self is consistent with the many references in the Upanişads to the Self being the "seed," "the source," "the creator." "In a person, indeed this one first becomes an embryo" (Aitareya Upanişad). [9] "It is the seed of all activity, that is to say, it is the state of deep sleep. That (mental state) is called jñānam, knowledge..." (Śańkarācārya). [8] By the fifth week after fertilization, the embryo cranium is bulging with midbrain that is firing spontaneously. This is the vital force. "It is like that which is known as the flash of lightning and it is also as though the eye winked" (Kena Upanişad). [2] "The vital force enters into the womb along with the seed and it develops itself into the embryo and all the other limbs such as the eye, the ears and the rest manifest themselves subsequently" (Sivananda). [10]

The embryo brain consists of the thalamus, hypothalamus, midbrain, and brainstem. These are the specific areas of the brain that are discernible about five weeks after conception. As the brain grows and expands, these areas remain the central core and guiding influence. It is mentioned in passing that the thalamus and hypothalamus comprise a part of the brain known as the diencephalons which also contains the pineal body. A special significance for this pineal body is given below when we come to the storage of long term memories in the embryo brain region during deep sleep.
The hypothalamus is responsible for the states of being awake or asleep which are pivotal in our lives. It is said to organize, when electrically stimulated, total acts of aggression, timidity, mating, and sexual behavior in animals. As to these last mentioned aspects, compare the content both of our dreams and our thoughts, where themes such as these regularly occur. In terms of human emotion, we would talk of hatred, fear, love, and desire. The hypothalamus apparently directs our mental processes from the very beginning, and is responsible for all our emotions. The hypothalamus is also considered responsible for the autonomic nervous system which directs all the myriad functions that take place in our body over which we have no conscious control-functions relating to circulation, respiration, digestion, excretion, regulation of body temperature and metabolism, regulation of water content, and reproduction. The fact that the hypothalamus remains a relatively small area in the developed adult brain merely attests to its potency, and to the fact that it was performing functions just as complex in the embryo period when it was very small indeed. Hence references in the Upanişads to the Self being of the size of a thumb or less. The entire embryo brain region in the adult brain is indeed about the "size of a thumb." The hypothalamus itself has a rostrocaudal extent of about $10 \mathrm{~mm}$. [11]

Compare the fact that the hypothalamus controls respiration with the passage in the Brhadäranyaka Upanişad, "That which breathes by the breath is thy soul which is within every being".[3] It is also known that the fetus in the womb practices breathing movements specifically during REM sleep.[12] Another factor indicating the workings of the Self in the embryo brain region; the source of respiration and dreams: "Now he who, without stopping the respiration, goes upwards, moving about yet unmoving, dispels darkness, he is the Self" (Maitreyi Upanişad). [5]

The thalamus has extensive connections with the higher regions of the brain and determines what will become conscious to us. Fibers from the thalamus are connected as well to neurons of the central nervous system, gustatory, auditory, visual, and from the skin, the organs of balance, the bladder, the alimentary canal, the muscles and joints. [13] The Upanişads speak about precisely these nerves emanating from the heart. "Again when (this person) is fast asleep, when (he) knows nothing whatsoever returning in the body with the 72 thousand nerves by name hita which proceed from the heart to all parts of the body, he sleeps". [10]

By five months of gestation, increased brain wave activity is noted with the onset of activity around the thalamus. [14] This is consistent with the thalamus acting as a mediator or "go-between" between the embryo brain and the higher regions of the fetus's brain that are by now substantially developed. And it is likewise consistent with the brain wave activity in the adult where there are $10 / \mathrm{sec}$ 
rhythmical brainwaves that are considered to comprise a loop between the cortical regions and the thalamus. [13] There are a number of theories about the precise pathway that the loop takes but the concept of the thalamus as a "go-between" is reinforced by Baron Edgar Adrian's observation that rhythmic thalamic activity persists even if substantial areas of the cortex are removed-indeed even if the whole cortex is removed! Further reinforcement comes from the theory that the thalamus acts as a central "pacemaker" for cortical rhythmical activity, which implies that command signals from a small thalamic region are distributed to wide areas of the cortical mantle. [13]

The importance of the brainstem is certainly on a par with the other areas of the embryo brain because a system of projections are in place here by the end of the embryo period (8 weeks) which influence the growth and development of the cortical (higher) regions. It is generally concerned with the states of arousal-sleeping, waking, relaxation, alertness, vigilance etc. Sensory input from the receptors does not reach the anatomical substrate of consciousness while we are asleep because of the operation of the brainstem; if the input is urgent it awakens. [15] "The nerve that rises upward from the heart is their passage for moving (from the dream state to the waking state); it is like a hair split into a thousand parts. (Numerous) Nerves of this body, called Hita are rooted in the heart" (Brhadāranyaka Upanişad). [6] "This Self (i.e., the subtle body) is surely in the heart. There are a hundred and one of the (chief) nerves. Each of them has a hundred (division). Each branch is divided into 72 thousand sub-branches. Among them moves the Vyāna" (Praśna Upanişad). [8]

There are many clues in the Upanişads that the Self is located in the embryo brain region in the center of the brain. For instance, very often the Self is simply described as being located in the middle. "After meditating on the Self seated in the middle of the heart like a lamp placed inside a vessel of the size of a thumb and of the form of smokeless flame (the Self manifests himself)" (Paińgala Upanişad). [9] "All deities worship that adorable one, the seated in the middle, who pushes the prāna upward and impels the apāna inward" (Kaţha Upanişad). [2] “... in the middle (between the two parts) there comes into being the divine person, the person, with a thousand eyes, a thousand feet and a thousand arms..." (Subāla Upanişad). [9] ("between the two parts" - the two hemispheres of the brain). These would all appear to be clear references to the embryo brain region. "Therein the individual soul who has established himself in the middle of the eyebrows..." (Paingala Upanişad). [9] It so happens that the spot in the middle of the eyebrows, the mystical third eye of Shiva, is directly in line with the embryo brain region in the middle of the brain.

We learn from neurophysiologists that when pieces of midbrain are isolated from the brain, the cells continue to fire spontaneously and in a sustained manner. [13] By "firing" is meant "synapses"- the nerve cells acquire electrical properties. When one considers that by the fifth week after fertilization the embryo cranium is bulging with midbrain, and given the spontaneous nature of midbrainal activity independently of the higher regions, it is apparent that we have a mental life from a very early age. This spontaneous firing of the midbrain is what the Bŗhadāranyaka Upanişad is referring to when it says, "it thinks as it were and quivers, as it were" "as in dream the mind vibrates" (Mānndūkya Kārikā). [8] Krishnananda says, "Even if there is a blazing sun in dream it is the mind shining" (Bŗhadārangyaka Upanişad). [4] The midbrain "shines" in the sense of spontaneous firing of nerve cells. "As from a blazing fire sparks of like form issue forth by the thousands even so many kinds of beings issue forth from the Immutable..." (Māndūkya Upanişad). [9]

The fact that the midbrain is directly connected with the eyes is the clue that it is the source of dreams. The Maitreyi Upanişad tells us that "The person who is in the eye, who abides in the right eye, he is Indra and his wife abides in the left eye... There is a channel extending from the heart up to the eye and fairly fixed there. That is the channel which serves both of them, by being divided in two though but one". [5] "That is the eye in a man through which one sees in a dream" (Vedic text). [8] The visual pathway runs forward from the midbrain to the eyes and backwards from the midbrain to the visual cortex at the back of the brain. The visual pathway is indeed "divided in two though but one" as the Maitreyi Upanişad says, in order to serve both eyes.

Dreams involve visual image and are therefore inextricably tied in with the visual pathway. Śankarācārya says, "and then a man whose eyes are plucked out should not perceive blue yellow etc., in dream" (Commentary on Aitareya Upanişad). [8] This is an allusion to the fact that only the color cone receptors in the retinae of the eyes can produce a color image in our dreams. It is apparent then that a dream image originates in the midbrain as an electrical impulse which then travels forward to the eyes where the impulse is converted into a color image - this is why dreams always involve eye movement either rapid or non-rapid - and from the eye back along the visual pathway to the visual cortex where the image is actually registered. It is therefore understandable that brain patterns during REM sleep (desynchronized) are practically identical with those during arousal. [15] The visual pathway comes into operation in both cases. Krishnananda says, "As in dream, so in waking, as in waking so in dream". [7] The midbrain "thinks as it were, and quivers, as it were. For being one with dreams, it goes beyond this (waking) world" (Bŗhadāranyaka Upanişad). [6]

"This is but the middle-part of the Self" (Chāndogya Upanişad) [5]; "Madhye āsinam-sitting in the middle - sitting in the space inside the lotus of the heart, shining in the intellect as revealed knowledge" (Śańkarācārya's Commentary on the Kaţha Upanişad). [2] "Abiding in the middle place, man sees both places, this 
and the place of the other world" (Brhadäranyaka Upanişad). [3] It is submitted that in the midbrain is located the cosmic intelligence, Brahman and Atman or the individual Self operates through the hypothalamus and thalamus as well as the brainstem. "The Supreme dwells in close fellowship with the individual self in the cave of the human intelligence" (Rangaramanuja-quoted by Radhakrishnan). [5] There are dozens of similar references in the Upanişads to this "guhā," this secret place, this cavity, this cave in the intellect which is $\bar{a} k \bar{a} s$ sa: space. "It is used as a name of the Supreme, because like a space, Brahman has no body and is subtle" (Radhakrishnan). [9] There is literally a cavity or space associated with the midbrain. The fourth ventricle is a broad shallow rhomboid-shaped cavity that extends from the upper cervical spinal cord to the cerebral aqueduct of the midbrain. [11] "The fourth state, Turiya" "the ether of the heart?" And it does arguably resemble the broad leaf of a lotus plant; hence the many references to the "lotus of the heart."

There are many references in the Upanişads to the Self being "unborn." "This great, unborn soul is the same which abides as the intelligent (soul) in all living creatures, the same which abides as ether in the heart; in him it sleeps; it is the subduer of all, the Ruler of all, the sovereign lord of all beings" (Bŗhadāranyaka Upanişad). [3] It is only when one grasps the significance of the sleeping state that the reference to the Self being unborn can be understood. From conception onwards the embryo is asleep, and the adult sleeper reverts precisely to that embryonic state of mind. The Self is located in the embryo brain region and preserves its embryonic identity. It is in this sense that the Self is "unborn." When an adult goes to sleep he/she mentally reverts to the mother's womb. "The talkers vouch indeed for the birth of that much unborn, positive entity. But how can a positive entity that is unborn and immortal undergo mortality?" (Mānndūkya Kārikā)[8] "(The Self) without being born (appears to be born in various ways), it follows that $\mathrm{He}$ is born on account of Māya alone" (Māndūkya Kārikā). [8] As Ŕg Veda says, "It is the controller of the body, the unborn part, which survives death."

\section{De Anima}

Aristotle's work is called De Anima which is Latin for "On the soul." The first thing to be noted is that this is obviously not the actual title that Aristotle gave his work. In fact, Aristotle's original work no longer exists and we only know of his writings as something that have passed through the hands of many editors and many different translators over the millennia. In fact, the English word "soul" conveys nothing of the meaning of the Ancient Greek word psyche. "The psyche, for Aristotle, is that in virtue of which something is alive. The most accurate translation of the term into English would be "principle of life' or 'principle of animation"'. [16] Aristotle's broad term psyche has been diversified in the hands of modern philosophers from Descartes onwards to mean "soul," "mind," or "consciousness" and indeed modern philosophers tend to follow Descartes and take a subjective or first-personal approach to all these various issues. Indeed Aristotle is considered to be old-fashioned or too simplistic with his objective or third-personal discussion of the psyche, but we will find that it is precisely the way that Aristotle discusses the functions of the psyche as something that enjoys an eternal existence independently of the body and yet at the same time is inextricable tied up with the arrangement and functioning of the body that makes his theory virtually identical with the Upanişads. For Aristotle, the psyche is the form of a living being and this is precisely what the inner self is as well.

The various functions of the embryo brain region of the brain outlined above demonstrate that the inner self has form and functions. In a like manner, the concepts of form and functions are very closely connected for Aristotle. It is because of a living thing's form that it can perform its functions, and conversely if you know its functions you can know its form. It is virtually a truism to state that the embryo brain of a cat will have the form of an embryo brain of a cat and it will produce in the cat after it is born all the various functions that a cat can perform and by virtue of this living being performing those functions we can know that we are dealing here with the form of a cat. This is Aristotle's theory in a nutshell. In terms of Hinduism, a cat has the inner self of a cat and will therefore perform the functions of a cat. What's more this form of being a cat is indelibly stamped on this being, and it will continue to be able to perform its functions of being a cat even if any or all of those functions are only being intermittently utilized; this thing that has the form of a cat cannot change its nature. Aristotle's psyche is the First Actuality of the living being and that is precisely what the inner self is as well. The second Actuality is the body in the actual performance of its functions. This is Aristotle's entelecheia, upon which all life depends. It is often objected that merely asserting as Aristotle does that the forms of living beings be called "souls" is not sufficient to explain what is peculiar to those things. That is of course true but we now know that these "souls" are actually the embryo brains of those living beings, and as such they do literally explain not only what is peculiar to those beings, but indeed they explain everything about them including their essence, their form, their capacities, and their functions.

As a general rule, the two main preoccupations of Presocratic Greek philosophy that Aristotle had to deal with were to find "an explanation of the capacity for self-movement displayed by living things and their no less remarkable capacity for various kinds of cognition".[16] Over the millennia, the debate started by the Ancient Greeks has raged whether the "soul" is substantial or 
insubstantial and if substantial what sort of substance is it, whether it is "physical" or "spiritual," and whether a "spiritual" soul can exist in a "physical" body or do the body and soul both have to be spiritual in order to co-exist, or indeed whether body and soul both have to be physical. In Presocratic philosophy, the standard view was that both body and soul can be physical. Generally speaking, the physical stuff the soul was composed of was one of the elements fire, air, and water or indeed a combination of these. Aristotle when dismissing these theories as being way too naïve drew some consolation in the fact that there was at least no theory that the soul was composed of the fourth element, earth. There was indeed another theory that the soul was composed of atoms that Aristotle largely dismissed as being essentially a soul composed of fire theory. This is a very simplistic overview of the Presocratic theories, and in fact there were some individual theorists like Anaxagoras with his nous, or mind as soul and Empedocles with his logos, or proportion as soul, which Aristotle tried to dismiss quite unconvincingly. There is also the Pythagorean theory that the soul consists of numbers which Aristotle rejected. Indeed this theory is generally taken to be ridiculous and stems from an over-exalted regard that Pythagoras had for mathematics. One wonders however whether Pythagoras won't eventually have the last laugh, because the soul might turn out to be nothing but information recorded in binary data, which is nothing but numbers. To the Pythagoreans is also attributed a very unmaterialistic notion of soul as "a substance of quite a different kind from those that compose the world, to whit an immortal god trapped in a succession of animate and even inanimate bodies". [16]

Broadly speaking, Aristotle is regarded as being the father of biology because he is considered to have put forward a Functional Approach in his ruminations about the "soul" that largely fits in with the mindset of modern scientists. But we will see that all the functions that he discusses as being evidence of the workings of the soul or the form and matter of the soul are the same or very similar to the functions that the Upanişads ascribe to the inner self. Broadly speaking, the embryo brain of a cat will have the specific form and matter of the embryo brain of a cat and a living creature will be born that has the "set of attributes" of a cat. What's more, throughout the life of this cat, the embryo brain region consisting of the brainstem, hypothalamus, thalamus, and midbrain will be the natural and appropriate controller of the body of that cat. There is nothing here that a modern biologist would disagree with and so Aristotle can be taken to be the father of the biology, but the fact remains that Aristotle's whole discussion is based on the form and matter or substance of the "soul" so there is nothing here that a Hindu versed in the Upanişads will disagree with either.

Just like in the Upanişads, the self is often described as being located in the "heart" so too with Aristotle the location of his soul was likewise taken to be the "heart" (this is the Instrumentalist or Heart theory of Nuyens). [16] The interesting fact is that for both Hinduism and for De Anima the actual functions or attributes that the inner self or the "soul" are said to perform or demonstrate actually all come from the embryo brain region, the brainstem, hypothalamus, thalamus, and midbrain. The fact is that the embryo brain region is the "heart" of the brain. Aristotle said that the soul was "the first entelechy of a natural body endowed with organs". [16] Substitute his word psyche with the Sanskrit word Atman or inner self and you have got classic Hinduism. Recall the quote from Rg Veda earlier "It is the controller of the body, the unborn part that survives death."

Aristotle's word eidos which is translated as form can mean on the one hand "the principle of organization of a thing which leads it to have its particular existence: on the other, in the sense that is usually translated 'species,' it means a sub-group of a genus or kind". [16] Also Aristotle's word ousia is generally translated as "substance" but it can also mean "being" or "essence" and in Aristotle's metaphysics in general it takes on a much wider meaning than simple "substance." Aristotle asserts that forms are substances and that souls are forms therefore concluding that souls are substances. [16] Once it is realized that the "soul" is the embryo brain region, then there is no ambiguity here whatsoever. For the embryo brain of a particular living being is at once the principle of organization of that being as well as defining the species that being belongs to and the substance or essence of that being, in addition to which the embryo brain does consist of matter in the conventional sense of the word. It is composed of material; it can be examined and studied; it has certain parts and dimensions and texture.

The embryo brain as soul is indeed immersed in the matter of the body. In book Zeta of his Metaphysics, Aristotle also favors a description of the soul as the substrate (to hupokeimenon). This again is most a propos for the embryo brain of any living being for it really is the logos of any living thing, and it represents the "fulfillment or realization" of the particular thing just as Aristotle requires. You can see that the embryo brain ticks all the boxes when it comes to Aristotle's discussion of the form, matter, and substance of soul and indeed Aristotle himself strongly hints that the soul is located in the embryo (see the quotation from Generation of Animals in the following section). We can also better understand Aristotle's insistence that the soul consists of form and matter and their composite. It is standard Aristotelian doctrine that there are gradations in the realization of any potential. $\mathrm{He}$ expresses this by saying that a composite particular may have a first and second actualization. It is in virtue of the first of these that its matter is so arranged as to render it capable of performing its characteristic functions and it is in virtue of the second that it "actually" performs them.[16]

During the embryo period, we see the first actualization of the embryo brain, and then after the creature is born we 
see the second actualization of the embryo brain as the embryo brain region of the developed brain. In other words, the embryo brain region continues to operate as the soul of the being throughout its life and the being will continue to have all its specific attributes and perform all its functions as a being of a particular species or genus precisely because of the continued operation of the embryo brain region in its secondary actualization.

The embryo brain region and the body of that being do indeed become a composite and both the matter of the soul and the matter of the body are perfectly homogenous. This is why Aristotle refers to the substance of the soul in book Gamma of his Metaphysics as the what-it-was-to-be-that-thing of a thing. [16] "It suggests the idea of what something was all along going to, destined to, become". [16] The first actualization of the soul is the embryo brain when the being is an embryo. But because the second actualization of the soul is the embryo brain region in the developed brain, then the ousia or essence of the soul can now only be referred to in the past tense. Your what-it-was-to-be-that-thing was your own embryo brain when you were an embryo! Your embryo brain was your first entelechy; the embryo brain region in your brain is your second entelechy. It's just that simple.

Aristotle then passes on to a detailed discussion of the various functions of the soul that are responsible for various attributes and capabilities of living beings. Call it the first comprehensive attempt to specify all the essential functions that can be found in living beings - typically in human beings - although the functions are arranged in a hierarchical fashion from the most basic like the nutritive function and reproductive function that will be typical of all beings including plants through to functions like imagination that will be found only in humans. This is why Aristotle is regarded as the father of biology. Indeed it is said of him that he anticipated the DNA as the First Principle. See the remark of Max Delbrueck, a professor at the California Institute of Technology, that "if the Nobel committee were able to award the prize for biology posthumously, they should consider giving it to Aristotle for the discovery of the principle of DNA". [16] Because modern biologists completely ignore the God factor in De Anima we can fairly readily come up with an Aristotelian First Principle they would be happy with:

Biology is the source of Consciousness;

DNA is the source of Biology;

Ergo DNA is the source of Consciousness.

This First Principle is also kosher with the Spinoza/Leibniz Principle of Sufficient Reason and represents the absolute limit to knowledge, because all knowledge must be produced by conscious beings. It's no use saying that western scientists will one day know everything there is to know about how consciousness works, because all such detailed knowledge will have to be produced by conscious scientists and will therefore likewise be subject to the First Principle. This is the problem of self-reference that was proposed by the mathematician Gödel.

Aristotle devotes the bulk of his discussion to sensory perception which is classic Hinduism and can have no meaning other than the soul being located in the embryo brain region. Another function of the soul is phantasia which is generally translated as "imagination." We have seen that the visual pathway runs forwards from the midbrain to the eyes and backwards from the midbrain to the visual cortex. The midbrain as the source of dream imagery would also be the source of phantasia, especially as Aristotle treats it as an "interpretative mental act in connection with perception" [16] as well as "a specific faculty that we possess to produce in our minds imagery related to, but not identical with, that of the sense". [16] The soul is also responsible for the motivation faculty in living beings. We have seen that the hypothalamus organizes total acts of aggression, timidity, mating, and sexual behavior in animals, and as for the causes of movement in animals then we need look no further than the motor thalamus that has extensive afferent connections to the premotor and primary motor cortex. [17] [18] Refer to earlier quote from Maitreyi Upanishad about the "Self moving about yet unmoving." The motor thalamus is Aristotle's "unmoved mover," and is an adjunct of God as the Unmoved First Mover.

Aristotle also discusses the intellect as an "affection" of the soul. Here again "Aristotle's account is manifestly open to the charge of attempting too great an assimilation of thinking to perception and especially to seeing" [16], so the operations of the hypothalamus and midbrain can largely account for this as well. As regards his notion of "the active intellect and passive intellect" even Aristotle's immediate successor at the Lyceum (Theophrastus) was already interpreting this as a distinction between "the mind in potentiality and the mind in actuality". [16] "Aristotle argues, in Metaphysics $I X$, that actuality is prior to potentiality. This means, among other things, that a potentiality must be understood in terms of some corresponding actuality. (Met. IX 8 1049b12-17)[19]

In book Lambda of his Metaphysics, "the Supreme Being is perpetually engaged in an activity that Aristotle calls noesis noeseos, which on the surface appears to mean "thinking of, i.e., about, thinking"".[16] This has clear counterparts in the cosmic intelligence Brahman and the individual self Atman of the Hindus. Evidently, the only way we can know anything about the "potentiality" which is Brahman is by inquiring into the "actuality" which is Atman or the inner self. It is clear from the following passage from De Anima [19] that the mind in potentiality is the separable and immortal part of the soul for Aristotle. It is only in as much as the individual soul is able to participate or share in the cosmic intelligence that living beings are able to think at all. It is in this sense that the 
cosmic intelligence is the productive mind and the individual soul is just a passive mind that is indeed perishable. Here again there are clear counterparts in Hindu theory.

Since just as in all nature something is matter for each genus (this is what is all those things potentially) and something else is the cause and is productive by producing all things (just as an art stands to matter), these differences must also exist in the soul. And one sort of mind exists by becoming all things, while another exists by making all things, as a sort of disposition like light. For in a way light makes potential colors into actual colors. And this mind is separable (chôristos), unaffected, and unmixed, since it is essentially in actuality. For the producer is always more honorable than the patient, and the principle is more honorable than the matter. Actual knowledge is the same as the object; but potential knowledge is prior in time in the individual, but on the whole, it is not prior even in time. But it is not the case that it sometimes thinks and sometimes does not think. Having been separated (choristheis) this is alone what it is, and this alone is immortal and eternal-but we do not remember because, while this is unaffected, the passive mind is perishable - and without this, nothing thinks. (III 5 430a10-25)

\section{Wherefore art Thou Endymion?}

It is only when we come to the realization that the divine part of the brain is the part of the brain that operates during our sleep, both dreaming and deep sleep, that we are able to come to a correct interpretation of the Upanişads. By the same token Aristotle in his Nicomachean Ethics refers to Endymion as the God in all of us that is permanently asleep (X 8 1074b15-18)[19], we have seen that from conception onwards that the embryo is in a state of sleep and that the embryo brain region is the part of the brain that operates during our sleep. There cannot be any doubt that the divine and separable part of our brain is in that embryo brain region whether you want to call it the divine inner self along with the Hindus or whether you want to call it the psyche or the nous along with Aristotle. "In a person, indeed this one first becomes an embryo" (Aitareya Upanişad). In the following quote from Aristotle's Generation of Animals, the word "origin" is synonymous with First Principle. There is no doubt whatsoever where the "soul" is located.

So, if there is such a part, which must be present in animals, one which has the origin and end of the entire nature, this must come to be first-as motive capacity, first, while as a part of the end it must come to be along with the whole... And on account of this, the part having the origin comes to be first, and then, following it, the upper trunk. It is for this reason that the parts around the head and the eyes appear largest in embryos at the start, while those below the umbilicus, such as the legs, are small. For the lower parts are for the sake of the upper and are neither part of the end nor generative of it. (742b12-17)

By five weeks after conception, the embryo cranium is bulging with midbrain that is firing spontaneously. This is what-it-was-to-be our soul.

Aristotle describes the soul in De Anima as "the first grade of actuality of a natural organized body" (412b4).[20] We have seen from his observation in Generation of Animals that the parts around the head and eyes of the embryo appear largest at the start and that here is to be found the origin of the being, that is to say its soul or first actuality. In fact Aristotle also recognizes that sleep comes first in the being and that wakefulness evolves later.[21] $\mathrm{He}$ actually says in De Anima "for both sleeping and waking presuppose the existence of soul, and of these waking corresponds to actual knowing, sleeping to knowledge possessed but not employed" (II,1, 412a23-26)[20]. Likewise in De Insomniis he refers to "those true thoughts which occur in sleep" (1.459a6-8). [20] Aristotle in Book 9 of Metaphysics refers to sleeping as the soul as potentiality and waking as the soul as actuality (IX, 6, 1048b1-2). [20] By 5 weeks after fertilization the embryo cranium is bulging with midbrain that is firing spontaneously. It is true that Aristotle believed in those first five weeks after fertilization that only the nutritive soul was present (Generation of Animals, II,1, 735a15-23 and II,3, 736a35-736b7).[20] He did not regard the first weeks of the embryo as being in a state of sleep per se, "but as something resembling sleep - the sort of state that plants also are in; indeed the fact is that at this stage animals are living the life of a plant."(Generation of Animals, 778b35-779a2)[20] But there can't be any doubt that he also believed that the true knowledge or the soul as potentiality was there as well.

Aristotle makes his position very clear by something he said in Eudemian Ethics when dealing with the pleasures of the actual waking life. Bear in mind here that he has elsewhere referred to Endymion as the god in all of us who is permanently asleep:

Nor...would anyone desire life for the pleasure of sleep either; for what is the difference between slumbering without being awakened from the first day till the last of a thousand or any number of years, and living a vegetable existence. Anyway plants seem to participate in life of that kind; and so do children too, inasmuch as at their first procreation in the mother, although alive they stay asleep all the time. (I, 5, 1216a3-8) 


\section{REM as Genetic Programming Mechanism}

It has been known for decades that the fetus in utero spends most of its time in a state akin to REM (Rapid-Eye-Movement) dreaming sleep. There also seems to be little doubt that this state of sleep is a key factor in the development of the central nervous system.[22] Michel Jouvet advanced the theory that certain genetic programs are periodically reinforced in the brain and this reinforcement first establishes and then maintains the functionality of the synaptic circuits responsible for our psychological heritage. He felt that such a system had the advantage of reestablishing certain circuits that may have been altered by epigenetic factors, which are factors not strictly determined by our genes. This genetic reprogramming occurs during the phase of sleep he called 'paradoxical sleep' also known as REM (Rapid Eye-Movement) sleep, which is generally considered to be the time when we dream.[23]

Jouvet advanced three keys for unlocking the enigma of paradoxical sleep. Firstly that dreaming mechanisms require a lot of energy through the consumption of oxygen. Secondly the likely reason why the so-called 'cold-blooded' animals, namely fishes, amphibians and reptiles do not appear to engage in paradoxical sleep is that their nerve cells continue to divide throughout the life of the animal. This is contrary to the situation with homothermal animals that maintain a constant body temperature independent of their external environment. The third key in relation to the latter species, namely mammals and birds, is that the more immature they are (in utero or in vivo) the more something resembling paradoxical sleep (referred to as 'active sleep') becomes important.

According to Jouvet, there are many studies that show a positive correlation between the immaturity of the nervous system and the fragility of the thermoregulation system of the neonate mammal, and the increased proportion of time spent in paradoxical sleep. A human neonate will spend 50 to 60 percent of its sleep-time in paradoxical sleep. A kitten or baby rat can spend up to 80 or 90 percent of its sleep-time in paradoxical sleep. This significant increase in paradoxical sleep has also been found to apply in utero for the fetuses of many mammal species. Jouvet points out that it is precisely at the time the nervous system is finishing its initial maturation and genetic programming that the amount of paradoxical sleep, which in due course will become dreaming sleep, attains its greatest proportions. After this initial maturation process the amount of paradoxical sleep gradually decreases. This has to be a very significant phenomenon.

Jouvet's primary research as a neurophysiologist was to locate the mechanisms in the brain responsible for paradoxical sleep. According to him the topography of neurons (more than likely cholinergic) that constitutes the endogenous generator of the activity ponto-geniculo-occipital (PGO) of dreaming has been defined precisely. It is situated in the reticular formation of the pons in the brain stem. The routes are also known whereby the PGO activity reaches the centers for motor ocularity, which causes the rapid-eye movements of dreaming sleep. The ascending paths leading to the cerebral cortex, either directly or via an intermediate thalamic relay have been equally defined with great precision.

By blocking the inhibitory system which prevents motor discharges during paradoxical sleep, Jouvet found that a sleeping cat will perform certain characteristic behavioral patterns as if it is acting out its dreams. The animal will get up quickly and start walking as if it is stalking an imaginary prey. It will then stop and demonstrate the characteristic gesture of catching a fish. Other stock actions can quickly follow. It may demonstrate fear with its ears back, or open its jaws wide in the snarling hiss of feline rage, or even feign an attack with quick backward movements of its paws and biting movements in thin air. It will also groom itself by licking its paws and flanks but it can equally start licking the perimeters or floor of its cage. Jouvet stresses that these behaviors occur without any external visual or auditory stimulus, and thus indicate that the dream is a programmed activity of the brain. In this context, he recalls a remark made by Piaget that a dream resembles a game inside the brain.

Jouvet fundamentally poses the perennial question of nature versus nurture. If dreams are a genetic programming mechanism for the brain, then they would be responsible for the individual variations in the instinctive activities and behaviors of animals as well as being responsible for human personality traits to the extent that they are innate or inherited. That is to say, that part of our psychological heritage which cannot be attributed to our environment, our culture or learning. If Jouvet is correct, the importance of dreams during our formative years cannot be overemphasized and our dreams continue to iteratively program the subtlest reactions of our waking consciousness throughout life.

Fetal movements are without doubt the expression of motor discharges caused by the genetically programmed formation of synapses during the maturation of the central nervous system, according to Jouvet. It is impossible to deny the influence of the environment in utero in the behavior and comportment of the neonate, and it is equally certain that the genetic program plays a predominant role in the stereotypical movements of approach to the mammary, of twitching and sucking which occur during periods of paradoxical sleep in the neonate.

For Jouvet, it is difficult to understand how a definitive genetic program established at the end of the initial maturation period can efficiently organize future innate behaviors given the plasticity in modifications of the synaptic connections induced by environmental causes. Furthermore, the definitive genetic program of hundreds of 
billions of synaptic connections would require a great many more genes than are known to exist in the genome. For these reasons, the concept of a recurrent or periodic genetic programming appears more satisfactory. This endogenous periodic process would excite at regular intervals the synaptic structures responsible for the recognition and processing of stimuli which produce stereotypical innate behavior. An obvious candidate for such a periodic genetic programming is paradoxical sleep.

\section{A Complete Explanation of Consciousness}

For David Hume our consciousness is simply a bundle of different perceptions. He denies the notion of a self, or soul, or substance that gives us a sense of continuity in these perceptions, and thus a personal identity. He admits however that we do have a notion of personal identity, and it is our memories that allow us to discover not produce our personal identity. It is thru memory that we raise up the images of past perceptions which enables us to see the chain of resemblance in these perceptions, thus giving them a notion of continuance. He says: "Had we no memory, we never should have any notion of causation, nor consequently of that chain of causes and effects, which constitute our self or person". (Treatise, 1.4.6.4; 1.4.6.18ff)

It was recently found that our long term memories are stored in the putamen during deep sleep.[24] The putamen is also in the embryo brain region along with the pineal gland that secretes melatonin during deep sleep.[25] The pineal gland is located in the center of the brain tucked into a groove where the two halves of the thalamus join.[25] The putamen is located at the base of the telencephalon adjacent to the thalamus.[26] Descartes famously located the soul in the pineal gland, and there is a high probability that the secretion of melatonin from the pineal gland is in fact an unconscious operation of the soul involved in storing our long term memories in the embryo brain region.

We have seen that the Upanishads are very clear that the Inner Self is the seed, the source, the creator of consciousness, and that it is the part of the brain that operates during sleep. It is proposed that from the Upanishads, Aristotle and Descartes we can come up with a unified theory of consciousness, namely from the very beginning when we are an embryo we are in a state of sleep, and that is precisely due to what the Hindus call the Inner Self and what Aristotle and Descartes call the soul. We have seen that the state of wakefulness comes about after the state of sleep when at the end of the $6^{\text {th }}$ month the eyelids of the fetus actually open. The eyelids opening are obviously an external factor and say nothing about what is going on in the brain to bring about this state of wakefulness. We have seen the theory of Michel Jouvet that REM dreaming sleep is a genetic programming mechanism of the brain. It is proposed that the self or soul is also responsible for the dreaming state and in fact our brain is programmed to achieve the waking state thru our fetal dreams. The ultimate explanation for consciousness is therefore that it comes to us out of the sleeping state and it is withdrawn from us back into that sleeping state, and that it has been programmed into our brain via our fetal dreams.

Before concluding, I just need to deal with one traditional objection to the notion of soul. If it is of the essence of the soul to be conscious, then what are we to say about sleep? If conscious attributes are necessary for the existence of the soul, in the way that physical and spatial attributes are necessary to the existence of the body, then what is to become of the soul during sleep? For we all believe that although sleep may contain periods of dreaming, it also contains a number of periods of unconsciousness. If I myself am a soul, an essentially conscious thing, then how is it possible for me to live in a state of complete unconsciousness? Here we see just to what extent mainstream scientists have misconstrued the problem of consciousness. The fact is that the part of the brain that operates during our sleep, which I call the embryo brain region, is not only our soul but it is our unconscious mind. To say that our soul draws us into sleep and then wakes us up again and gives us waking conscious, is merely saying that we have an unconscious mind and a conscious mind, and that our conscious mind is born out of our unconscious mind. When we are asleep the soul withdraws into itself just as the Upanishads say.

\section{Conclusions}

To conclude, I just want to quote to you the conclusion of Willam James in his Varieties of Religious Experience. [27] Western science has had a scientific and psychological explanation for the unconscious soul for more than 100 years. James says: "The subconscious self is nowadays a well-accredited psychological entity; and I believe that in it we have exactly the mediating term required. Apart from all religious considerations, there is actually and literally more life in our total soul than we are at any time aware of. What Mr. Myers said in 1892 in his essay on the Subliminal Consciousness is as true as when it was first written: "Each of us is in reality an abiding psychical entity far more extensive than he knows - an individuality which can never express itself completely through any corporeal manifestation. The Self manifests through the organism; but there is always some part of the Self unmanifested; and always, as it seems, some power of organic expression in abeyance or reserve." Let me then propose, as a hypothesis, that whatever it may be on the farther side, the 'more' with which in religious experience we feel ourselves connected is on its hither side the subconscious continuation of our conscious life."

The only thing I have added to James' hypothesis is to locate this unconscious soul in the embryo brain region of 
our brain, and to identify the unconscious operations of our soul as the mental processes that occur during sleep, both dreaming and deep sleep. Of course now that we know that the hither side of the unconscious soul is in the embryo brain region then the farther side cannot be that far away. Indeed the farther side can be no further away than the DNA. Refer back to my Aristotelian First Principle:

Biology is the source of Consciousness

DNA is the source of Biology;

Ergo DNA is the source of Consciousness.

Or the shorter version of this: DNA IS CONSCIOUSNESS. Having said that, once we know that our consciousness comes to us out of our sleeping state, then all that we can really say about life is that we appear to wake up, and when we do wake up we have a consistent set of memories about having woken up previously.

\section{REFERENCES}

[1] Bartholomew, B.Y., (1991) Inner Self Located, Indian Philosophical Quarterly, 18(4)

$<$ http://unipune.ac.in/snc/cssh/ipq/english/vol18_4.htm>.

[2] Eight Upanişads Vol. 1. (1986) Calcutta: Advaita Ashrama.

[3] Doer, E., (1978) Bŗhadāraņyaka Upanişad. Delhi: Nag Publishers.

[4] The Bŗhadāranyyaka Upanişad. (1984) Swami Krishnananda; the Divine Life Society, Tehri- Garwahl.

[5] Chāndogya Upanişad. (1983) Calcutta: Advaita Ashrama.

[6] The Bŗhadāranyyaka Upanişad. (1951) Sri Ramakrishna Math; Madras.

[7] The Bŗhadāranyyaka Upanişad. (1984) Swami Krishnananda; The Divine Life Society, Tehri- Garwahl.

[8] Eight Upanişads Vol. 2. (1957) Calcutta: Advaita Ashrama.

[9] The Principal Upanişads. (1989) S. Radhakrishnan; Oxford University Press, Delhi.

[10] The Bŗhadāranyaka Upanişad. (1985) Swami Sivananda; The Divine Life Trust Society, Tehri-Garwahl.

[11] Carpenter, M. B. (1978) Core Text of Neuroanatomy. Baltimore: Williams \& Wilkins.

[12] Liggins, G.C. (1972) Embryonic and Fetal Development. In Austin, C. R. \& Short, R. V. (Eds.). The Fetus and Birth.

[13] Remond, A. (Ed.). (1972) Handbook of
Electroencephalography and Clinical Neurophysiology, Volume 2A, Section 5, Thalamo-Telencephalic Circuits: A Neuroanatomical Survey, 2A-86, Volume 2C, Section 4, Thalamic Origin of Cortical Rhythmic Activity, 2C-90, Section 5, Reticular Influences on Thalamo-Cortical Activity, 2C-119.

[14] Pecile, A. \& Muller, E. E. (Eds.). (1971) The Ontogenesis of Hypothalamic-Hypophysiotropic Releasing Factor Regulation of High Secretion. Selna L. Kaplan \& Melvin M. Grumbach. International Symposium on Growth Hormone; Proc. of 2nd Int. Symp. on Growth Hormone; Milan.

[15] Gregory, R. L. (Ed.). (1987) The Oxford Companion to the Mind. See generally, Brain Development, Catecholamines, Dopamine Neurones in the Brain, Nervous System, Neuroanatomical Techniques, Neuropeptides, Neurotransmitters and Neuromodulators, Visual System: Organization.

[16] Lawson-Tancred, H., (1986) Aristotle, De Anima (On the Soul) (Classics). Penguin Books Ltd. Kindle Edition.

[17] Fang, P. C., Stepniewska, I. \& Kaas, J. H. (2006) The Thalamic Connections of Motor, Premotor, and Prefrontal Areas of Cortex in Prosimian Primate (Otolemurgarnetti). Neuroscience 143.4.

[18] Orrison Jr., W. (2008) Atlas of Brain Function. New York: Thieme Medical Publishers Inc.

[19] Shields, C. (Ed.) (2012) The Oxford Handbook of Aristotle (Oxford Handbooks). Oxford University Press. Kindle Edition.

[20] Sprague, R.K. (1977) Aristotle and the Metaphysics of Sleep, The Review of Metaphysics, 31.2.

[21] Papachristou, C.S. (20140 Aristotle's Theory of 'sleep and dreams' in the Light of Modern and Contemporary Experimental Research. Electronic Journal for Philosophy, 17.

[22] Roffwarg H., Muzio, J., \& Dement, W. (1966) Ontogenetic development of Sleep-Dream cycles, Science, 52,604 - 619.

[23] Jouvet, M. (1992) Le sommeil et le rêve [The sleep and the dream]. Paris: Odile Jacob

[24] Vadat, S., Fogel, S., Benali, H., \& Doyon, J. (2017) Network-wide reorganization of procedural memory during NREM sleep revealed by fMRI, eLife; 6:e24987.

[25] Macchi M, Bruce J (2004). "Human pineal physiology and functional significance of melatonin". Front Neuroendocrinol. 25 (3-4): 177-95.

[26] Youngson, R.M. (2004) Putamen Collins Dictionary of Medicine.

[27] James, W. (1982) Varieties of Religious Experience. Penguin American Library. 